\title{
EMITTER CLOGGING IN A RECLAIMED WATER IRRIGATION SCHEME WITH CONTROLLED SUSPENDED LOAD
}

\author{
M.M.H. OLIVER ${ }^{1,2}$, D. PEZZANITI ${ }^{1,2}$ \& G.A. HEWA ${ }^{1,2}$ \\ ${ }^{1}$ SA Water Centre for Water Management and Reuse, University of South Australia, Mawson Lakes, SA 5095, Australia. \\ ${ }^{2}$ School of Natural and Built Environments, University of South Australia, Mawson Lakes, SA 5095, Australia.
}

\begin{abstract}
Emitter clogging in drip irrigation system is a very common problem when used with reclaimed water. The suspended solids from treated water are the major elements of clogging mechanism. Coupled with bacterial biofilms, these particulates can reduce the flow of emitters by creating barriers in the flow path. This experimental study reports the performance of three types of pressure compensated emitters in a drip irrigation system. Reclaimed water with a sediment load of $10 \mathrm{mg} / \mathrm{l}$ was supplied in the system throughout the experiment. Four ranges of particle sizes $(0-45,45-90,90-150$, and $150-300 \mu \mathrm{m})$ were used during $770 \mathrm{~h}$ of intermittent irrigation. Low flow emitters $(<2 \mathrm{l} / \mathrm{h})$ were found to be clogged quicker than those with higher flow rates. Though flushing of the system did not help in discharge recovery of the partially clogged emitters, it helped regain the lateral flow. The interior geometry of biofilms was found to be built only by the smaller particles. Larger particles $(>50 \mu \mathrm{m})$ only appeared around the perimeters of matured biofilms making the surface topography very coarse and undulating.
\end{abstract}

Keywords: Clogging, emitters, particle size, reclaimed water, suspended load.

\section{INTRODUCTION}

Clogging of emitters in drip irrigation system has been a major problem for irrigators. Introduction of reclaimed water as an alternative source of irrigation has only made the scenario more complex in recent years. As a consequence of clogging, the discharge of individual emitters changes significantly resulting in poor performance of the irrigation system. In subsurface drip irrigation (SDI) schemes, the scenario is more problematic. As the SDI emitters are buried under a soil cover, it is difficult to identify the clogged emitters and expensive to replace. Recent studies have shown three distinctive kinds of clogging agents in reclaimed water irrigation (RWI) schemes [1-3]. These are named as physical, chemical and biological clogging, which directly correspond to the quality of reclaimed water. Biological components of recycled water play the most important role in initiating the process of clogging [4]. Previous studies have reported the presence of an extensive microbial diversity in reclaimed water [5-8]. When the emitters remain inactive, the microbes in water adhere to the emitter wall. Followed by adherence, they colonise by secreting slimy gelatinous-type substance that forms biofilms [9]. Made of exo-polymeric substance (EPS), this biofilm is, in fact, a complex structural assembly [10]. The EPS mainly constitutes protein and carbohydrate which give the biofilm a shape and structural unity. This collects the micro particles in reclaimed water. As more particles are trapped in, the clogging biomass grows thicker and stronger inside the emitter flow path. Eventually, the whole passage is blocked, which results in significant reduction of the emitter's flow rate.

At the initial stage of clogging, both physical and biological processes contribute to the development of clogging biomass [11,12]. However, the process becomes truly physical when total irrigation time increases. Recent biophysical studies on clogging have reported the presence of a range of particle sizes in the clogging biomass $[8,11,13]$. Particles in the range of $60-300 \mu \mathrm{m}$ was first reported by Adin and Sacks [14] introducing the idea that comparatively larger particles are responsible for emitter blockage. The suspended solid (SS) level in water is, therefore, one of the most 
important determinants of clogging. There have been attempts to recommend acceptable levels of SS concentration in RWI schemes [12,15]. These recommended values also vary with the size of the drippers. In case of emitters with shorter and wider labyrinths, the acceptable limit of SS that leads to minor clogging hazard can be increased to as high as $200 \mathrm{mg} / \mathrm{l}$ [1]. Reclaimed water for irrigation usually come with low sediment level. SS level under $50 \mathrm{mg} / \mathrm{l}$ is considered 'safe' for low flow emitters. However, this threshold is also controversial as it does not specify the size of the particulates. Besides, severe clogging has also been observed in schemes where SS level was far below the acceptable limit. Ravina et al. [16] observed variable degree of clogging in drip irrigation systems. Later studies have also acknowledged that partially clogged emitters appear more frequently in a system than the fully clogged ones $[1,3,8,13]$. They also showed that the appearance of any partially/ fully clogged emitters is not evenly distributed in a system. It was reported [1] that emitter clogging is more prominent at the tail end of laterals. This phenomenon is explained by the accumulative deposition of particles in the pipe, which is merely a mechanical problem that leads to clogging. Li et al. [17] reported the surface topography of particulates in relation to the clogging mechanism. Their results showed strong correlation between particles of definable shape in reclaimed water and those in the biomass. It was claimed that particles in reclaimed water were mainly porous and encapsulated by slimy EPS. However, no specific size of particle was attributed to the occurrence of clogging events.

Preventive measures to overcome clogging have also remained ineffective for emitters. Among other techniques, chlorination [18], acid injection [19] and flushing the drip lines [20] have been tried to regain the system flow together with filtration [21]. Chlorination with $1 \mathrm{ppm}$ free chlorine in water and bimonthly flushing has been proven to be effective in RWI schemes with basic filtration [22]. Using screen filters have been preferred [22] in drip irrigation over other filtering technologies. As described above, all these recommendations about particle size $(30-300 \mu \mathrm{m})$, particle load $(<50 \mathrm{mg} / \mathrm{l})$, flushing frequency (bimonthly), and chlorination (1 ppm free chlorine) have been obtained from separate studies. Accounting all these recommendations in an ideal framework to investigate clogging of emitters can lead to significant results. It is, therefore, important that we understand clogging in light of recommendations from these previous research studies using modern biochemical techniques.

An experimental drip irrigation system has been developed in this regard at the University of South Australia to investigate clogging. The test rig containing multiple features of temperature and sediment control was developed to examine the performance of subsurface emitters. RWI during the test resulted in emitter clogging in the system. The results obtained from several physical and biochemical analyses are presented here along with the interpretation of the correlations among various experimental factors.

\section{METHODOLOGY}

\subsection{Emitter profiles}

The experiment consisted of three different kinds of pressure compensating (PC) emitters from three manufacturers. The design discharge for E1, E2 and E3 was 1.6, 2 and 2.3 1/h, respectively. They were embedded in 13-mm polyethylene tubing and spaced at every $30 \mathrm{~cm}$. Labyrinth dimensions of these emitters were also different to each other as shown in Fig. 1. These dimensions were obtained by the authors after analysing the scanning electron microscope (SEM) images of the emitters. The compensating range of pressure for these devices ranged from 40 to $400 \mathrm{kPa}$. According to the manufacturer's specification, these emitters are designed for RWI and can be used both for surface and subsurface drip systems. The manufacturing coefficient of variation $\left(\mathrm{CV}_{m}\right)$ of these emitters was 
calculated to be $0.05,0.03$ and 0.03 for E1, E2 and E3, respectively, through a pre-experimental test run. According to the existing standards [23,24] for predicting the performance of drippers, the $\mathrm{CV}_{m}$ of these emitters are within the most acceptable range.

\subsection{Reclaimed water}

Reclaimed water was obtained from the Bolivar wastewater treatment plant (WWTP) situated at the northern agricultural plains of South Australia. The plant uses dissolved air flotation and filtration method in treatment process followed by tertiary disinfection. Sodium hypochlorite $(\mathrm{NaOCl})$ has traditionally been used as the source of chlorine to disinfect the reclaimed water [25]. Like most WWTPs, the primary disinfection in this plant is also achieved by targeting $1 \mathrm{ppm}$ of free chlorine in the final product. The water was collected from the plant in large container $(5 \mathrm{ml})$ and stored near the experimental rig. After the collection, no additional chlorination was done during the experiment which is the general farming practice.

Water samples were collected for the analysis after every $110 \mathrm{~h}$ of irrigation time (500 $\mathrm{h}$ of experimental time). The SS level in water was measured even more frequently (every five days of operation). Major water quality parameters are presented in Table 1 along with their standard deviations.
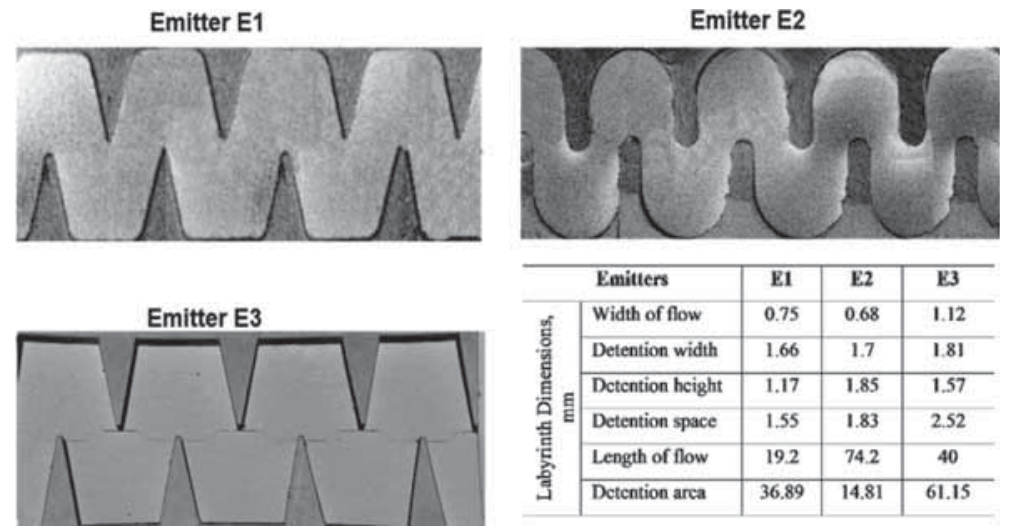

\begin{tabular}{|c|c|c|c|c|}
\hline \multicolumn{2}{|r|}{ Emitters } & E1 & E.2 & $\mathbf{E 3}$ \\
\hline \multirow{6}{*}{ 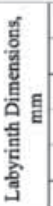 } & Width of flow & 0.75 & 0.68 & 1.12 \\
\hline & Detention width & 1.66 & 1.7 & 1.81 \\
\hline & Detention height & 1.17 & 1.85 & 1.57 \\
\hline & Detention space & 1.55 & 1.83 & 2.52 \\
\hline & Length of flow & 19.2 & 74.2 & 40 \\
\hline & Detention arca & 36.89 & 14.81 & 61.15 \\
\hline
\end{tabular}

Figure 1: Flow path structure and dimensional properties of the emitters.

Table 1: Reclaimed water quality over the experimental period.

\begin{tabular}{llllll}
\hline Parameters & \multicolumn{2}{l}{ Concentration, mg/l } & Parameters & \multicolumn{2}{l}{ Concentration, mg/l } \\
\hline Calcium & 41.8 & $(2.8)$ & Free chlorine & 0.5 & $(0.3)$ \\
Magnesium & 47.6 & $(2.9)$ & Iron & 0.27 & $(0.1)$ \\
Nitrogen & 14.6 & $(1.5)$ & COD & 23 & $(1.5)$ \\
Phosphorus & 1.7 & $(0.1)$ & TDS & 1450 & $(163)$ \\
Organic Carbon & 43.17 & $(1.9)$ & Bicarbonate & 152.4 & $(7.6)$ \\
& $\mathrm{pH}$ & & & 7.2 & $(0.8)$ \\
\hline
\end{tabular}

Note: Values inside the parentheses are the standard deviations from the corresponding mean over the experimental period. 


\subsection{Particle load and filtration}

The reclaimed water had a very low particle load $(<1 \mathrm{ppm})$, hence was perfectly suitable for this experiment. In light of the ideal recommendations (Section 1), an organic particle load of $10 \mathrm{ppm}$ was introduced to the reclaimed water. The load was in fact a mixture of four specific ranges of particle sizes. Table 2 summarises all the different particle sizes and the name of their separates according to the USDA soil separation classification system [26]. Contribution of these size ranges in the mixture was equally $(25 \% \mathrm{w} / \mathrm{w})$ distributed. The particles were oven-dried at $105^{\circ} \mathrm{C}$ for $24 \mathrm{~h}$ before being mixed with water. The idea behind this was to prevent any alien microbial contribution to the water apart from what is already in there. Water samples were collected at every five days of operation in triplicates and tested for total SSs in water. Any reduction in particle load was then immediately filled up with additional particles to achieve the threshold $(10 \mathrm{mg} / \mathrm{l})$. A screen filter was used to provide basic filtration in the system with $150 \mu \mathrm{m}$ pore size. It was fitted immediately before the feeding sub-main (Fig. 2). The quarter of the particle load above $150 \mu \mathrm{m}$ was, therefore, induced to assess the performance of bimonthly flushing needs.

\subsection{Experimental assembly}

A large drip irrigation testing chamber $(5 \mathrm{~m} \times 4 \mathrm{~m})$ was built at the Australian irrigation and hydraulic testing facility in the University of South Australia. The facility includes a large environmental chamber above the ground with thermal control features. This chamber houses a drip irrigation system with 12 laterals (Fig. 2). The emitters in the laterals are classified as 'subsurface type' by the manufacturer. In a typical experimental set up, laterals of three emitter types were placed $50-\mathrm{cm}$ apart from each other and replicated four times. Each lateral was 4.5-m long accommodating 15 emitters connected to sub-mains on both ends. Reclaimed water from the large container $(5 \mathrm{ml})$ was transferred to a smaller tank $(0.7 \mathrm{ml})$ built adjacent to the test rig. A centrifugal pump was coupled at the bottom of the tank, which supplied water into the drip assembly. Pressure gauges were installed on both ends of the sub-mains (Fig. 2).

\subsection{Experimental cycle}

Irrigation was scheduled for $8 \mathrm{~h}$ a day for two consecutive days and the third day was kept nonoperative, i.e. 2 days on and the next day off. This cycle was followed until the end of the experiment

Table 2: Particle size distribution in the reclaimed water and their classification.

\begin{tabular}{lcl}
\hline Particle size, $\mu \mathrm{m}$ & $\begin{array}{c}\text { Contribution to the } \\
\text { mixture }(\%), \mathrm{w} / \mathrm{w}\end{array}$ & Name of organic separates* \\
\hline $0-45$ & 25 & $\begin{array}{l}\text { Clay }(0-2 \mu \mathrm{m}) \\
\end{array}$ \\
$45-90$ & 25 & Silt $(2-45 \mu \mathrm{m})$ \\
$90-150$ & 25 & Very fine sand \\
$150-300$ & 25 & Fine sand \\
& & Fine sand $(150-250 \mu \mathrm{m})$ \\
& Medium sand $(150-300 \mu \mathrm{m})$ \\
\hline
\end{tabular}

*According to the USDA soil separation classification system. 


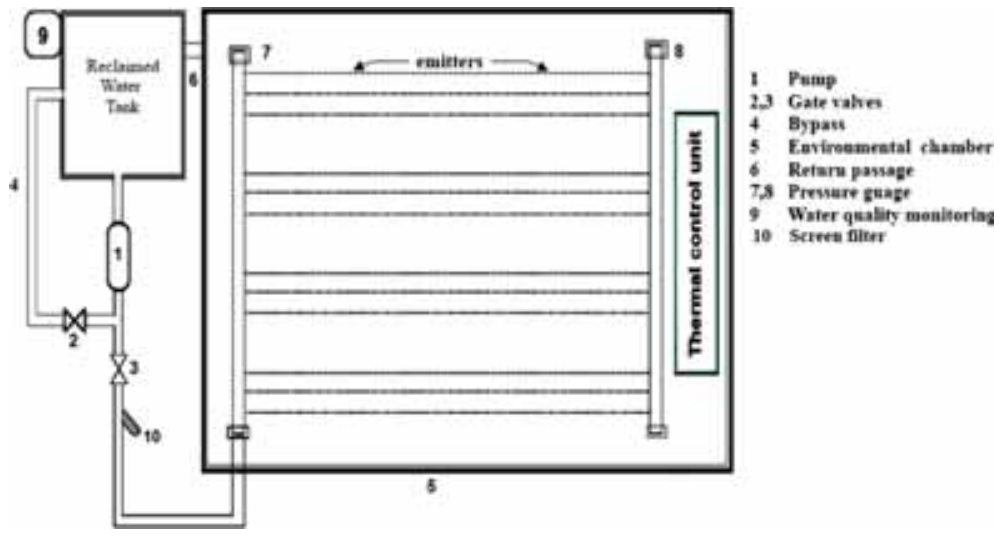

Figure 2: Experimental set up of the subsurface drip assembly.

during which a total of $760 \mathrm{~h}$ of irrigation was given. The total experimental period of $3600 \mathrm{~h}$ includes both irrigation period $(760 \mathrm{~h})$ and the non-operative hours. As presented in this paper, 110 $\mathrm{h}$ of irrigation time corresponds to the $500 \mathrm{~h}$ of total experimental time. Emitter discharges were measured from 36 randomly selected drippers after each $110 \mathrm{~h}$ of intermittent irrigation. Small plastic containers $(600 \mathrm{ml})$ of known weight were placed under the emitters for 5 min to collect the emitted water. The volume was then translated into emitter flow rate $(1 / \mathrm{h})$. All the measurements were conducted according to the standard ISO guideline [27]. During these measurements, the water and the ambient temperature were corrected up to $23^{\circ} \mathrm{C}$. The pressure variation along the laterals was kept within $2 \%$ of the design pressure $(100 \mathrm{kPa})$. Two dedicated pressure gauges and three control valves were installed for this purpose. Flow from the emitters would fall on a collector platform underneath and run into the $0.7 \mathrm{ml}$ tank. From here, the water was again recirculated into the system. Emitter samples were collected from each replication in triplicates after every $500 \mathrm{~h}$ of experimental run (110 $\mathrm{h}$ of irrigation time) to check for the degree of clogging. The samples were cut out from the laterals using sharp knives. After obtaining the sample replicates, the pipe flow was restored by joining the split section using barbed lateral connectors. The length of these straight connectors was the same as that of the emitters which kept the laterals in their initial length.

\subsection{Performance evaluation}

The hydraulics of an emitter flow is defined by the equation proposed by Keller and Karmeli [28] who showed that the flow rate $(q)$ is a function of the pressure head $\left(h_{0}\right)$ :

$$
q=k h_{0}^{x}
$$

The values of $x$ and $k$ are constants for a particular emitter type, which can be determined experimentally. In this experiment, ISO [27] standard procedure was followed in determining these constants. The pressure in the system was changed from 50 to $400 \mathrm{kPa}$ at an interval of $50 \mathrm{kPa}$. The corresponding discharges were measured following the procedure described in Section 2.5. These two sets of data were then plotted in logarithmic scales, and the values of $x$ and $k$ were obtained as shown in Table 3. When the subsurface emitters are laid underground, a spherical saturated zone around the point source was observed by Philip [29]. It was noted that a positive pressure head $\left(h_{s}\right)$ develops 
around the emitter head when the surrounding soil is saturated. Assuming that $h_{s}$ will have negative impact on the emitter discharge $(q)$, Shani and Xue [30] and Warrick and Shani [31] adjusted the above equation as follows:

$$
q=k \times\left(h_{0}-h_{s}\right)^{x}
$$

However, Gil et al. [32] explained that the effect of such external pressure on PC emitter discharge is very low $(<0.8 \%)$. Therefore, surface and subsurface discharges can be taken almost as identical to each other. The experimental discharge in this study can, therefore, be taken as the actual subsurface discharge of the emitters. Reduction of mean discharge $\left(q_{\text {red }}\right)$ for individual emitters was calculated according to Liu and Huang [33] as

$$
q_{\text {red }}=100\left(1-q_{r}\right)
$$

where is the relative discharge, which is expressed by the ratio of average emitter flow in a lateral $(\bar{q})$ to their design discharge $\left(q_{n}\right)$.

Distribution uniformity, $\mathrm{DU}_{1 / 4}[28]$, is frequently being used to describe the overall system performance in SDI schemes, which was calculated as follows. It uses the average of lower quartile discharge $\left(q_{1 / 4}\right)$ to calculate the index as follows:

$$
\mathrm{DU}_{1 / 4}=100\left(\frac{q_{1 / 4}}{\bar{q}}\right)
$$

In drip irrigation, statistical uniformity (SU) is widely used to report the emission uniformity. This was proposed by Wilcox and Swailes [34] and later adopted by Bralts et al. [35]. However, SU mathematically corresponds to the Christiansen uniformity (CU) coefficient [36] and is not representative of the system performance. It was, hence, used to describe the emission uniformity of emitters along laterals as follows:

$$
\mathrm{SU}=100(1-\mathrm{CV})=100\left(1-\frac{\mathrm{SD}_{q}}{\bar{q}}\right)
$$

$\mathrm{CV}$ is the statistical coefficient of variation of emitter discharges along a lateral and $\mathrm{SD}_{q}$ is the standard deviation from the mean discharges.

\subsection{Electron microscopy}

The particle surface topography can be helpful in defining how particles adhere to the surfaces in the biofilms. A total of 54 emitter samples were collected during the experiment and one-third of them were analysed under a SEM. Though biofilms grew all over the emitter, we sectioned a $3 \mathrm{~mm} \times 3 \mathrm{~mm}$ strip of the labyrinth section from each emitter. The strips were then fixed with phosphate-buffered saline, and sucrose (4:4) at slightly alkaline condition for a period of $2 \mathrm{~h}$. After washing, the samples were post-fixed in a $2 \%$ osmium tetroxide solution and dehydrated by a series of ethanol gradient (70-100\%).

To dry the samples, a chemical drying agent called hexa-methyl-di-silazane was used. Finally, the samples were sputter coated with platinum and observed under an electron microscope (Quanta $2000)$ at $10 \mathrm{kV}$. For characterising the particles in water, the same procedure was followed for sample preparation except that the samples were obtained by filtering the reclaimed water through a micro filter paper. Images were taken at a range of magnifications $(500-25,000)$ and four particle sizes were reported. To obtain the labyrinth dimensions (Fig. 1), emitter flow paths were also 
photographed under the SEM. The Image-J software was then used to analyse the structural orientation of the particles in biofilms and the flow path structure of the emitters.

\section{RESULTS AND DISCUSSION}

\subsection{Particles in water}

The particle size distribution in water, as explained earlier, was characterised by equal contribution ( $25 \%$ from each size) of the four particle sizes. This even distribution was maintained until the end of the experiment. When samples were collected for analysis after every $500 \mathrm{~h}$ of experimental run, many of the particles in water were found to have been coupled by bacterial biofilms as shown in Fig. 3. Smaller particles in reclaimed water appeared very porous (Fig. 3a) and surrounded by bacterial slimes within and in-between the pores. Particles up to $50-\mu \mathrm{m}$ in size were affected by biofilm growth around their perimeter. These particles varied from very definable shape to very irregular and anomalous geometric configuration.

Interestingly, larger particles ( $>100 \mu \mathrm{m})$ appeared to have less biofilms on their surfaces (Fig. 3c). The abundance of slimes around smaller particles can be explained by their relatively small surface area and porous structure. The voids in the particles are easily accessed by the microbes in water during the non-turbulent times. Once accessed, it becomes easier for the microbes to remain attached to the smaller particles by encircling the perimeter as shown in Fig. 3b. Large perimeter of the particles in the range of 100-300 $\mu \mathrm{m}$, on the other hand, makes it difficult for the microbes to maintain such colonies, especially, during turbulence. Growth of biofilm has been reported in almost every surface that comes in contact with reclaimed water [37,38]. However, the degree of growth depends on how favourable it is for the biological components of water to actively propagate on a particular surface. It appears from the analysis that the larger particles do not support extensive microbial growth around their perimeter. Li et al. [17] studied the surface topographic characteristics of suspended particles using fractal theory. Their results partially conform to the findings of this study.

(a)

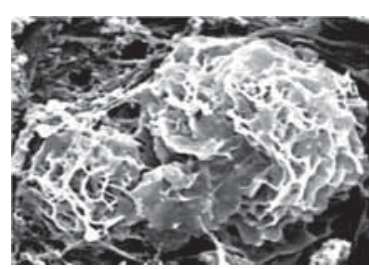

(c)

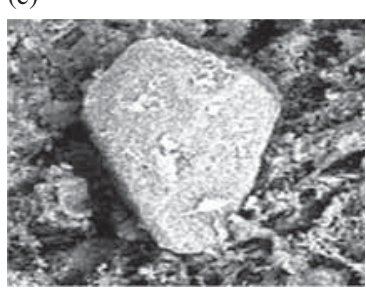

(b)

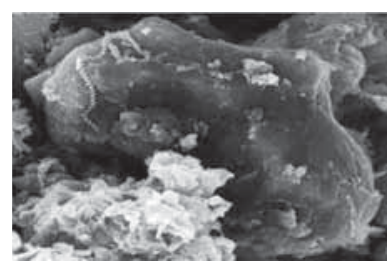

(d)

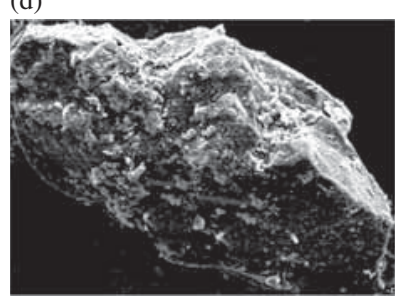

Figure 3: Particle sizes (a) $2 \mu \mathrm{m}$ at $\times 25000$, (b) $20 \mu \mathrm{m}$ at $\times 15000$ (c) $50 \mu \mathrm{m}$ at $\times 7000$, and (d) $100 \mu \mathrm{m}$ at $\times 2500$ magnifications in reclaimed water. 
It was shown that the suspended particles in reclaimed water are flocculent and porous [39]. The uniformity of distribution of these pores was reported to be increasing with the size of the solids. The results of this experiment indicate that higher uniformity of distribution in larger sedimentary pores does not encourage biomass growth. Smaller particles are, therefore, important candidates for clogging because they support more biomass in and around them. In the reclaimed water, particles $>150$ $\mu \mathrm{m}$ diminished gradually over time because of the filtration arrangements, and at the end of each 110 -h treatment they became rare. These results are being explained in light of the interior structure of biofilms in Section 3.3.

\subsection{Emitter performance}

The pressure compensation range of emitters is affected by the emitter exponents, $x$ and $k$ (eqn. 1 ). For PC emitters, the value of $x$ is theoretically 0 . However, a complete compensation is not possible as the existence of a very small value for this exponent has been recorded by many researchers $[1,3,13]$. The values of these variables for the emitters in this experiment have been provided in Table 3.

The values of emitter exponents $(x)$ in Table 3 suggest that effective compensation is possible at the design pressure $(10 \mathrm{kPa})$. In this experiment, the pressure variation along the laterals was kept minimal as described in Section 2.5. Therefore, any variation in emitter discharge during the experiment can be taken as the result of clogging. This variation is better presented by the relative measure of flow change. As can be seen from Fig. 4, the reduction of emitter discharge was well below 5\% up to the second intermittent measurement. However, response of E1 to clogging at any time was quicker than the other emitters at the same time. By the first $330 \mathrm{~h}$ of irrigation (1500 h of total experimental time in Fig. 4), when E1 was emitting 10\% less than their design discharge, the other

Table 3: Hydraulic exponents of the PC emitters.

\begin{tabular}{cccccc}
\hline \multicolumn{2}{r}{ Emitter, E1 } & \multicolumn{2}{c}{ Emitter, E2 } & \multicolumn{2}{c}{ Emitter, E3 } \\
\hline$x$ & $k$ & $x$ & $k$ & $x$ & $k$ \\
0.01 & 1.5 & 0.02 & 1.9 & 0.01 & 2.1 \\
\hline
\end{tabular}

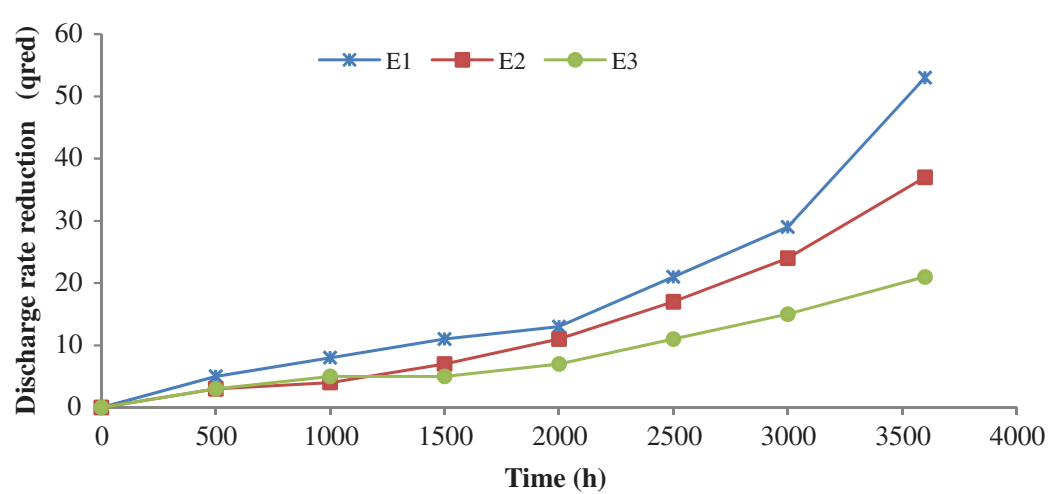

Figure 4: Reduction of emitter discharges with total experimental time during the experiment. 
emitters were still showing small changes in the emitting pattern (Fig. 4). In fact, E2 and E3 performed in similar manner during this period of irrigation. It was only after the third stage of irrigation when sharp changes were observed in emitter flow. Between 1500 and $2500 \mathrm{~h}$ of this experiment, emitter discharges for E1 and E2 had been reduced by almost a quarter of their design discharge. Ravina et al. [16] concluded that a reduction of $10 \%$ or more should indicate the initiation of clogging. Therefore, the reduction of flow in E1 and E2 proves that the clogging biomass had already passed the initial stage. However, during the same time, emitter E3 showed better anti-clogging performance by restricting the reduction of flow within $11 \%$ of its initial discharge (Fig. 4).

The overall scenario indicates that the fouling process was consistently low at the initial stage of this experiment. However, during the middle stages, rapid changes took place. Compared with the changes in the first and middle stages, the results of the final stages of this experiment showed drastic responses. A steep decrease in the flow rate was observed for all the emitter types in the final stages (Fig. 4). The flow rate of emitter E1, in particular, had been reduced by more than half (53\%) of its design discharge after $760 \mathrm{~h}$ of irrigation ( $3600 \mathrm{~h}$ of total experimental period). Emitter E2 responded in a similar manner but with less reduction (37\%). The laterals with E3 was least affected by clogging, as the average final discharge was reduced only by $21 \%$. It has been reported [40-41] that low flow emitters $(2-4$ 1/h) are prone to clogging. However, it appears from the results that even under the ideal set of conditions, lower flow emitters $(<2 \mathrm{l} / \mathrm{h})$ are also prone to clogging. Bucks et al. [12] and Boswell [15] classified the clogging risk of low discharge emitters (2-4 1/h) in relation to water quality. According to their specification, suspended load of $50 \mathrm{mg} / \mathrm{l}$ possesses minor clogging risk. The discharge reduction of E3 $(2 \mathrm{l} / \mathrm{h})$ under $10 \mathrm{ppm}$ load in this experiment proves that notion. However, the performance of E1 $(1.6 \mathrm{l} / \mathrm{h})$ stands clearly in contrast. Therefore, it can arguably be said that the existing classification is not adequate for emitters with flow rate $<2 \mathrm{l} / \mathrm{h}$.

The coefficient of variation of the emitter discharges in the system increased with the total experimental time and was translated into the SU for the laterals. The uniformity indices obtained during the experiment are being presented in Fig. 5. It is evident from the trend that uniformity indices of all these emitters did not show any significant change until the third stage of the experiment $(1500 \mathrm{~h})$. The results of discharge reduction also suggest that the fouling process during this time was very slow. However, the following two stages (next $1000 \mathrm{~h}$ ) were very significant when the average $\mathrm{DU}_{1 / 4}$ for E1, E2 and E3 dropped by almost 35\%, 23\% and 16\%, respectively (Fig. 5). This large fall critically explains the poor performance of the system after $2500 \mathrm{~h}$ of the total experimental period.

The SU index corresponds to the variability of discharge along the laterals. It gives some indication about the emitter behaviour at a particular time in the system. Ravina et al. [16] concluded that the coefficient of variation is a better indicator to describe the initiation of clogging. It was also reported that clogging is migratory in laterals. It can, therefore, be argued that the SU does not explain the overall systems uniformity, which is of more importance. The results from this study showed that the SU index for the laterals dropped to $51 \%, 67 \%$ and $79 \%$ for E1, E2 and E3, respectively, at the end of this experiment. However, these changes in SU were almost linear from the very beginning and did not provide any information about the phases of clogging. On the other hand, substantial changes in the low quarter distribution uniformity were observed throughout the experiment, which critically explains the phases of clogging at different times. The effect of clogging became evident from the changes in $\mathrm{DU}_{1 / 4}$ particularly after $1500 \mathrm{~h}$ of experimental time by which $330 \mathrm{~h}$ of active irrigation had been applied (Fig. 5a and c).

Bimonthly flushing of the system was found effective in increasing the total lateral discharge. The frequency seemed adequate for the particular sediment load used in this experiment. However, the individual emitters did not show any significant discharge recovery after flushing. It is probably because most of the clogging biomass grow and remain trapped under the diaphragm. Since the 


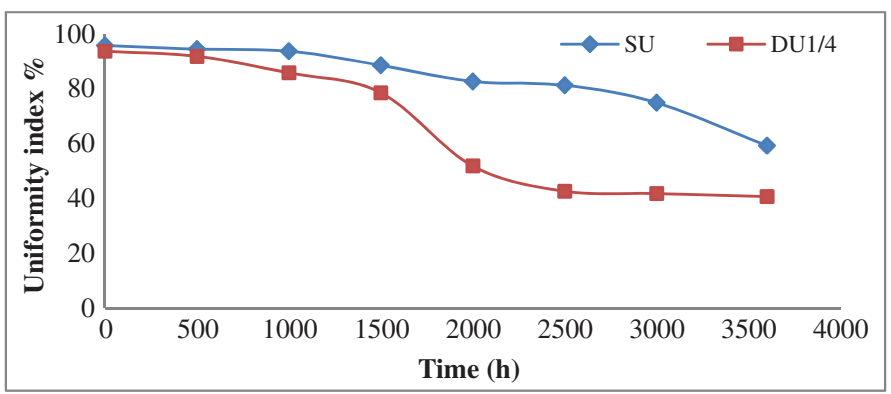

(a)

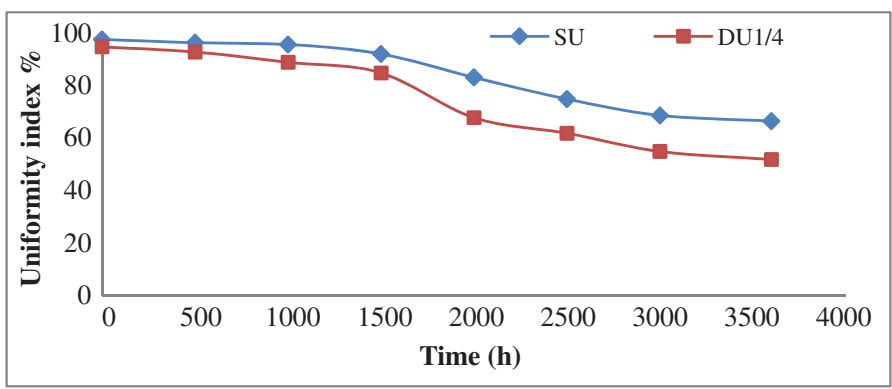

(b)

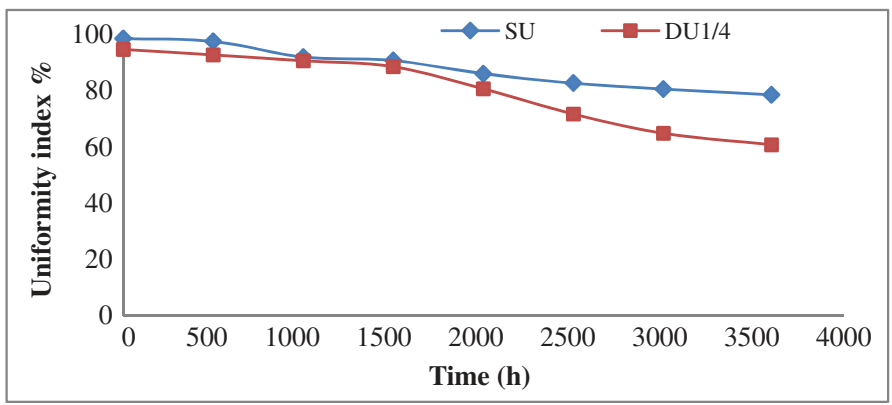

(c)

Figure 5: Variation of uniformity indices with the total experimental time for (a) emitter, E1; (b) emitter, E2 and (c) emitter, E3.

diaphragm sustains a constant pressure, a high-velocity flushing does not have any major effect on the flow regimes of the labyrinths. As a result, though total lateral flow increases, individual emitter flow does not show any important change. It explains that the flushing needs for any system should be determined based on the pressure drop in the laterals when reclaimed water comes with higher level of SS.

\subsection{Clogging biomass}

The growth of biofilms was observed both inside the emitters flow path and the lateral wall. The biomass attached to the lateral wall was mainly composed of heavier particles coupled with bacterial biofilms. On the other hand, biofilms attached to the flow path appeared very gelatinous and porous 


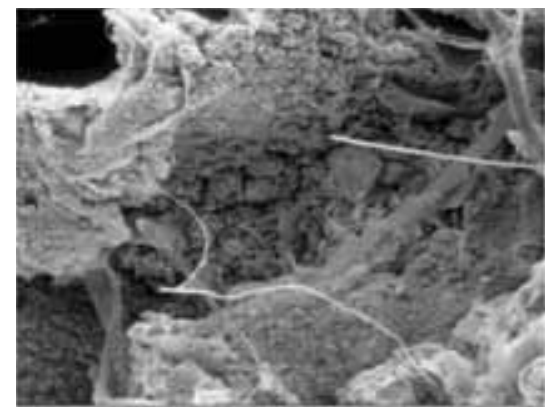

(a)

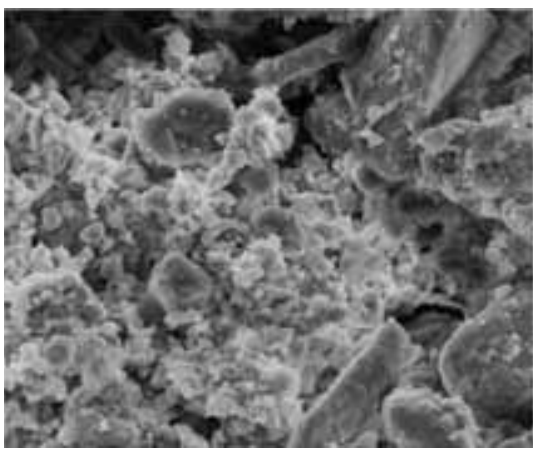

(c)

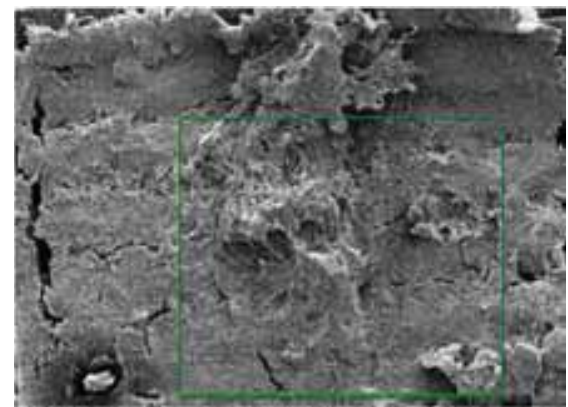

(b)

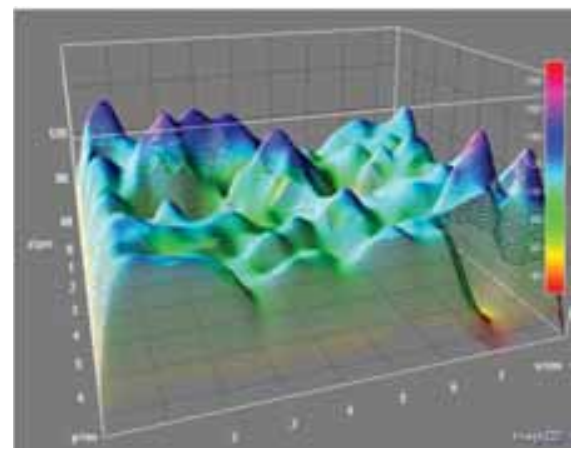

(d)

Figure 6: (a) Interior and (b) exterior of the biomass matrix; (c) range of particles in the matrix, and (d) 3-D interactive view of the surface topography of the average $(n=18)$ biofilms.

containing a range of particle sizes. A closer microscopic inspection revealed a three-dimensional geometric arrangement of the biofilm interior (Fig. 6a and c).

The gelatinous secretions of microbial species created a hetero-structural geometry in the clogging biomass with large adsorption capacity and undulating friction surface (Fig. 6d). As a result, any microparticle (Fig. 6c) coming in contact with the biofilm surface was adsorbed in the matrix. Li et al. [39] explained that lower hydrodynamic forces in drip laterals are actually responsible for this kind of adsorption. As more particles entered the geometry, the thickness of biofilms increased consistently over time. At the end of this experiment, the highest thickness (14-16 $\mu \mathrm{m})$ was observed in emitter E1, followed by E2 $(9-13 \mu \mathrm{m})$ and E3 $(6-10 \mu \mathrm{m})$. The external surface of the biofilms was found very rough, which signifies that some detachment of cells occur from the matrix. It happens mainly when flushing is achieved with higher velocity. The coarse friction surfaces (Fig. 6b and d) also suggest that any minor clogging event can be aggravated if larger particles are deposited on the exterior. As in this experiment, larger particles $(50-100 \mu \mathrm{m})$ were found on the surface of biofilms, whereas the structural backbone of the biofilms was mainly composed of smaller particles (0-30 $\mu \mathrm{m})$ coupled with bacterial EPS and organic residues. It suggests that the lower quartile particle sizes $(0-45 \mu \mathrm{m})$ are mainly responsible for the structural unity of biofilms. So far, scientific endeavours and operational practices in drip irrigation have been concentrated on reducing the total suspended load of reclaimed water. The results of this experiment, however, suggest that particle sizes should also be taken into account particularly, the porous and finer particles that sustain more biomass. 


\section{CONCLUSIONS}

The anti-clogging performance of the three pressure compensated emitters varied throughout the experiment. Low flow emitters $(1.6 \mathrm{l} / \mathrm{h})$ were clogged rapidly when used with reclaimed water even under a very low suspended load. Flushing of the system did not affect the discharge recovery of individual emitters but was effective in regaining total lateral flow. The surface topography of particles in water samples varied from very porous to very solid. Smaller particles $(<50 \mu \mathrm{m})$ appeared surrounded by bacterial biofilms. They were also found in abundance inside the clogging biomass. Majority of the particles trapped inside the biomass were $<20 \mu \mathrm{m}$ leading to the idea that the structural integrity of biofilms is dependent on smaller particles. Larger particles were observed outside the matured surface of the biofilms and helped aggravate the clogging mechanism. Considering the results obtained, this study concludes that the particle sizes in reclaimed water sediments should be carefully proportioned when used in RWI schemes.

\section{REFERENCES}

[1] Capra, A. \& Scicolone, B., Water quality and distribution uniformity in drip/trickle Irrigation systems. Journal of Agricultural Engineering Research, 70(4), pp. 355-365, 1998. doi: http:// dx.doi.org/10.1006/jaer.1998.0287

[2] de Kreij, C., Burg van der, A.M.M. \& Runia, W.T., Drip irrigation emitter clogging in Dutch greenhouses as affected by methane and organic acids. Agricultural Water Management, 60(2), pp. 73-85, 2003. doi: http://dx.doi.org/10.1016/s0378-3774(02)00159-2

[3] Clark, A.E., Subsurface Drip Irrigation: Wastewater Treatment Solution. Department of Biological and Agricultural Engineering, Masters Thesis, Kansas State University, US, pp. 3-9, 2008.

[4] Nakayama, F.S. \& Bucks, D.A., Water-quality in drip/trickle irrigation - A review. Irrigation Science, 12(4), pp. 187-192, 1991. doi: http://dx.doi.org/10.1007/bf00190522

[5] Marshall, K.C. \& Characklis, W.G., Biofilms, Wiley and Sons: New York, pp. 731-796, 1990. doi: http://dx.doi.org/10.1016/0167-7799(91)90057-o

[6] Raunkjaer, K., Hvitved, Jacobsen, T. \& Nielsen, P.H., Measurement of pools of protein, carbohydrate and lipid in domestic wastewater. Water Research, 28(2), pp. 251-262, 1994. doi: http://dx.doi.org/10.1016/0043-1354(94)90261-5

[7] Keinänen, M.M., Korhonen, L.K., Lehtola, M.J., Miettinen, I.T., Martikainen, P.J., Vartiainen, T. \& Suutari, M.H., The microbial community structure of drinking water biofilms can be affected by phosphorus availability. Applied and Environmental Microbiology, 68(1), pp. 434-439, 2002. doi: http://dx.doi.org/10.1128/aem.68.1.434-439.2002

[8] Persyn, R.A., Lesikar, B.J. \& Duan, X.J., Uniformity of domestic wastewater effluent application in a subsurface drip distribution system. Water Environment Research, 79(7), pp. 701-706, 2007. doi: http://dx.doi.org/10.2175/106143007x156808

[9] Lemon, K.P., Earl, A.M., Vlamakis, H.C., Aguilar, C. \& Kolter, R., Biofilm development with an emphasis on Bacillus subtilis. In Bacterial Biofilms, ed. Tony Romeo, Springer: Heidelberg, Germany, pp. 1-16, 2008. doi: http://dx.doi.org/10.1007/978-3-540-75418-3_1

[10] Pennanen, T., Liski, J., Bååth, E., Kitunen, V., Uotila, J., Westman, C.J. \& Fritze, H., Structure of the microbial communities in coniferous forest soils in relation to site fertility and stand development stage. Microbial Ecology, 38(2), pp. 168-179, 1999. doi: http://dx.doi.org/10.1007/ s002489900161

[11] Li, Y., Liu, H., Yang, P. \& Wu, D., Analysis of tracing ability of different sized particles in drip irrigation emitters with computational fluid dynamics. Irrigation and Drainage, 62(3), pp. 340-351, 2013. doi: http://dx.doi.org/10.1002/ird.1737 
[12] Bucks, D.A., Nakayama, F.S. \& Gilbert, R.G., Trickle irrigation water quality and preventive maintenance. Agricultural Water Management, 2(2), pp. 149-162, 1979. doi: http://dx.doi. org/10.1016/0378-3774(79)90028-3

[13] Ould Ahmed, B., Yamamoto, T., Fujiyama, H. \& Miyamoto, K., Assessment of emitter discharge in microirrigation system as affected by polluted water. Irrigation and Drainage Systems, 21(2), pp. 97-107, 2007. doi: http://dx.doi.org/10.1007/s10795-007-9022-6

[14] Adin, A. \& Sacks, M., Dripper-clogging factors in wastewater irrigation. Journal of Irrigation and Drainage Engineering, 117(6), pp. 813-826, 1991. doi: http://dx.doi.org/10.1061/ (asce)0733-9437(1991)117:6(813)

[15] Boswell, M., Micro-irrigation Design Manual, James Hardie Irrigation: El Cajon, California, pp. 3(1)-9(5), 1990.

[16] Ravina, I., Paz, E., Sofer, Z., Marcu, A., Shisha, A. \& Sagi, G., Control of emitter clogging in drip irrigation with reclaimed wastewater. Irrigation Science, 13(3), pp. 129-139, 1992. doi: http://dx.doi.org/10.1007/bf00191055

[17] Li, Y., Liu, Y., Li, G., Xu, T., Liu, H., Ren, S., Yan, D. \& Yang, P., Surface topographic characteristics of suspended particulates in reclaimed wastewater and effects on clogging in labyrinth drip irrigation emitters. Irrigation Science, 30(1), 43-56, 2011. doi: http://dx.doi.org/10.1007/ s00271-010-0257-x

[18] Trooien, T.P., Lamm, F.R., Stone, L.R., Alam, M., Rogers, D.H., Clark, G.A. \& Schlegel, A.J., Subsurface drip irrigation using livestock wastewater: dripline flow rates. Applied Engineering in Agriculture, 16(5), pp. 505-508, 2000. doi: http://dx.doi.org/10.13031/2013.5301

[19] Camp, C.R., Subsurface drip irrigation: a review. Transactions of the ASAE, 41(5), pp. 13531367, 1998 doi: http://dx.doi.org/10.13031/2013.17309

[20] Puig-Bargués, J., Lamm, F.R., Elbana, M., Duran-Ros, M., Barragán, J., de Cartagena, F.R. \& Arbat, G., Effect of flushing frequency on emitter clogging in microirrigation with effluents. Agricultural Water Management, 97(6), pp. 883-891, 2010. doi: http://dx.doi.org/10.1016/j. agwat.2010.01.019

[21] Yavuz, M., Dem rel, K., Erken, O., Bahar, E. \& Devec ler, M., Emitter clogging and effects on drip irrigation systems performances. African Journal of Agricultural Research, 5(7), pp. 532-538, 2010.

[22] Capra, A. \& Scicolone, B., Emitter and filter tests for wastewater reuse by drip irrigation. Agricultural Water Management, 68(2), pp. 135-149, 2004. doi: http://dx.doi.org/10.1016/j. agwat.2004.03.005

[23] Burt, C.M., Rapid field evaluation of drip and micro-spray distribution uniformity. Irrigation and Drainage Systems, 18(4), pp. 275-297, 2004. doi: http://dx.doi.org/10.1007/s10795-0042751-x

[24] Smajstrla, A.G., Boman, B.J., Haman, D.Z., Pitts, D.J. \&Zazueta, F.S., Field Evaluation of Microirrigation Water Application Uniformity, Institute of food and agricultural sciences: University of Florida, 1997.

[25] Keremane, G.B. \& McKay, J., Successful wastewater reuse scheme and sustainable development: a case study in Adelaide. Water and Environment Journal, 21(2), pp. 83-91, 2007. doi: http://dx.doi.org/10.1111/j.1747-6593.2006.00062.x

[26] Minasny, B. \& McBratney, A.B., The Australian soil texture boomerang: a comparison of the Australian and USDA/FAO soil particle-size classification systems. Soil Research, 39(6), pp. 1443-1451, 2001. doi: http://dx.doi.org/10.1071/sr12139

[27] International Standard Organisation (ISO), Agricultural Irrigation Equipment-emitters and Emitting Pipe-specifications and Test Methods, ISO 9261:2004 (E): Geneva, 2004. 
[28] Keller, J. \& Karmeli, D., Trickle irrigation design. Transactions of the ASAE, 17(4), pp. 678-684, 1974. doi: http://dx.doi.org/10.13031/2013.36936

[29] Philip, J., What happens near a quasi-linear point-source. Water Resources Research, 28(1), pp. 47-52, 1992. doi: http://dx.doi.org/10.1029/91wr02600

[30] Shani, U. \& Xue, S., Soil-limiting flow from subsurface emitters. I: pressure measurements. Journal of Irrigation \& Drainage Engineering, 122(5), pp. 291-295, 1996. doi: http://dx.doi. org/10.1061/(asce)0733-9437(1996)122:5(291)

[31] Warrick, A.W. \& Shani, U., Soil-Limiting flow from subsurface emitters. II: effect on uniformity. Journal of Irrigation and Drainage Engineering, 122(5), pp. 296-300, 1996. doi: http:// dx.doi.org/10.1061/(asce)0733-9437(1996)122:5(296)

[32] Gil, M., Rodriguez-Sinobas, L., Sanchez, R. \& Juana, L., Procedures for determining maximum emitter discharge in subsurface drip irrigation. Journal of Irrigation and Drainage Engineering, 137(5), pp. 287-294, 2011. doi: http://dx.doi.org/10.1061/(asce)ir.1943-4774.0000299

[33] Liu, H. \& Huang, G., Laboratory experiment on drip emitter clogging with fresh water and treated sewage effluent. Agricultural Water Management, 96(5), pp. 745-756, 2009. doi: http:// dx.doi.org/10.1016/j.agwat.2008.10.014

[34] Wilcox, J.C. \& Swailes, G.E., Uniformity of water distribution by some under tree orchard sprinkler. Journal of Scientific Agriculture, 27, pp. 565-583, 1947.

[35] Bralts, V., Edwards, D. \& Wu, I.P., Drip irrigation design and evaluation based on the statistical uniformity concept. Advances in Irrigation, 4, pp. 67-117, 1987. doi: http://dx.doi. org/10.1016/b978-0-12-024304-4.50005-5

[36] Christiansen, J.E., Irrigation by Sprinkling. Bulletn 670. University of California, Agric. Exp. Stn.: Berkeley, California, pp. 121-124, 1942.

[37] White, D., Davis, W., Nickels, J., King, J. \& Bobbie, R., Determination of the sedimentary microbial biomass by extractible lipid phosphate. Oecologia, 40, pp. 51-62, 1979. doi: http:// dx.doi.org/10.1007/bf00388810

[38] Smith, C.A., Phiefer, C.B., Macnaughton, S.J., Peacock, A., Burkhalter, R.S., Kirkegaard, R. \& White, D.C., Quantitative lipid biomarker detection of unculturable microbes and chlorine exposure in water distribution system biofilms. Water Research, 34(10), pp. 2683-2688, 2000. doi: http://dx.doi.org/10.1016/s0043-1354(00)00028-2

[39] Li, G., Li, Y., Xu, T., Liu, Y., Jin, H., Yang, P., Yan, D., Ren, S. \& Tian, Z., Effects of average velocity on the growth and surface topography of biofilms attached to the reclaimed wastewater drip irrigation system laterals. Irrigation Science, 30(2), pp. 103-113, 2011. doi: http://dx.doi. org/10.1007/s00271-011-0266-4

[40] Capra, A. \& Scicolone, B., Recycling of poor quality urban wastewater by drip irrigation systems. Journal of Cleaner Production, 15(16), pp. 1529-1534, 2007. doi: http://dx.doi. org/10.1016/j.jclepro.2006.07.032

[41] Oliver M.M.H., Hewa G.A. \& Pezzaniti D., Subsurface drip irrigation with reclaimed water: issues we must think now. WIT Transactions on Ecology and the Environment, Vol. 168, WIT Press, 2012, ISSN 1743-3541, doi.10.2495/SI120171. doi: http://dx.doi.org/10.2495/si120171 